\title{
Numerical Investigation of Iron Ore Tailings Filled Epoxy Composite as Heat Resistant Material
}

\author{
*Vivian N. Mbagwu, Olayinka O. Adewumi, and Modupe A. Onitiri \\ Department of Mechanical Engineering, University of Lagos, Akoka, Nigeria \\ vivibelenu@gmail.com I \{oadewunmi I monitiri\}@unilag.edu.ng \\ ORIGINAL RESEARCH ARTICLE \\ Received: 18-OCT-2021; Reviewed: 13-NOV-2021; Accepted: 04-DEC-2021 \\ http://dx.doi.org/10.46792/fuoyejet.v6i4.715
}

\begin{abstract}
The thermal properties of epoxy composites reinforced with iron ore tailings were used to investigate the thermal performance of the composite as heat resistant material. Thermal properties are important parameters for determining the behaviour and appropriate applications of materials. This paper focuses on investigating the thermal performance of epoxy composite reinforced with iron ore tailings (IOT) of particles sizes $150 \mu \mathrm{m}, 10 \%$ reinforced. The thermal properties of the selected epoxy-IOT composite were specific heat capacity $2352 \mathrm{~J} / \mathrm{kg}-\mathrm{K}$, thermal resistivity $-4.788^{\circ} \mathrm{C}-\mathrm{m} / \mathrm{W}$, thermal diffusivity $-0.089 \mathrm{~mm} / \mathrm{s}$ and Thermal conductivity $-0.209 \mathrm{~W} / \mathrm{m}-\mathrm{K}$. The selected epoxy-IOT composite was numerically compared with an existing material (gypsum board) of the following thermal properties: specific heat capacity $-1090 \mathrm{~J} / \mathrm{kg}-\mathrm{K}$, thermal resistivity $-3.87^{\circ} \mathrm{C}-\mathrm{m} / \mathrm{W}$, thermal diffusivity $-0.333 \mathrm{~mm}^{2} / \mathrm{s}$ and Thermal conductivity $-0.258 \mathrm{~W} / \mathrm{m}-\mathrm{K}$. The numerical analysis was done using Autodesk Fusion360, by modelling the materials as slabs. The heat transfer process of the composite and the prediction of the heat resistance capability were explained by comparing the results with an existing material (gypsum plasterboard) using their mechanical and thermal properties. The numerical results indicated that the epoxy-IOT composite has lower minimum temperature and thermal stress compared with the existing material (gypsum board), which implies that epoxy-IOT composite when used as a heat insulator will resist heat and sustain thermal stress better than the gypsum board of the same geometry under the same conditions. In conclusion, an epoxy-IOT composite of appropriate mixing ratio and geometry can be comfortable use as heat resistant materials.
\end{abstract}

Keywords- Epoxy-IOT, Numerical Analysis, Temperature Distribution, Thermal Performance, Thermal Stress

\section{INTRODUCTION}

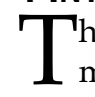
he engineering materials such as polymers have made a great advancement in their application compared to other materials such as metal, paper, glass and leather due to their unique properties and as such, have been used for different functions such as fire resistance, water proof, sound proof, wear resistance, e.tc. The properties of these engineering materials are the link between the basic structure, the composition of the material and service performance. These engineering materials are majorly composites created by reinforcing polymer (matrix material) with filler such as fibers, talc, sisal, bamboo, coconut fur, jute, glass fibers, or particles to improve or modify their properties and application (Ouyang, 2005). The determination of feasible properties of composites is a basic requirement for material selection and many engineering applications (Van Dommelen, Brekelmans, and Baaijens, 2003). These properties are affected by the size, nature and spatial distributions of the reinforcement (Ravichandran and Liu, 1995).

In this paper, the filler used is iron ore tailing (IOT), which is a by-product generated from the exploration of iron ore by mining industry. This exploration process diminishes the solid impurities bonded to the iron ore, consequently, generating an ore of greater iron composition but leading to excessive percentage of tailings (Adepoju and Olaleye, 2001). The thermal properties of different loading of epoxy-IOT have been determined and compared to achieve a mixed ratio that will serve as the best thermal insulator.

\footnotetext{
${ }^{*}$ Corresponding Author

Section D- MATERIALS/ CHEMICAL ENGINEERING \& RELATED SCIENCES Can be cited as:

Mbagwu V.N., Adewumi O.O., and Onitiri M.A. (2021): Numerical Investigation of Iron Ore Tailings Filled Epoxy Composite as Heat Resistant Material, FUOYE Journal of Engineering and Technology (FUOYEJET), 6(4), 386391. http://dx.doi.org/10.46792/fuoyejet.v6i4.715
}

The thermal properties that measured are thermal conductivity, thermal resistivity, thermal diffusivity and specific heat capacity. The thermal conductivity of the epoxy filled IOT is lower than the epoxy resin in its pure state (i.e., without IOT) because IOT reduces the thermal conductivity of the material. Thus, the composite can be used as a thermal resistance material by reducing/preventing heat flow from one place to another. Research works have been conducted on the thermal behaviour of several materials. For instance, Onitiri and Akinlabi (2017) developed a model to experimentally analyzed the impact of the particulate size and volume loading on the tensile strength and stiffness of epoxy and polypropylene filled with iron ore tailing (IOT) particles and the results were compared with different theoretical models. It was deduced from the result that the composites increased in stiffness as the volume content of the iron ore tailings particles were increased. Iron ore tailings have the potential to be used as a fine aggregate due to their particle size being significantly larger than that of cement and they are relatively inert.

This current work focuses on the numerical investigation of the thermal performance of iron ore tailings filled epoxy composite for heat resistance applications. The result would be compared with existing material (gypsum board). Gypsum plasterboard has been used by construction industries for many purposes outside the use of walls or ceilings, such as fire safety. They are mainly utilized as a lining material in lightweight construction, which is an efficient and cost-effective method of providing lithe partitioning assemblies in commercial and residential Buildings (Rahmanian, 2011).

\section{Methodologies}

The thermal properties of the epoxy-IOT composites were determined using a KD2 pro thermal properties analyzer. The equipment can read the thermal properties of 
different materials such as ceramics, polymers, rubbers, composites, glasses, even some metals, and other materials of low medium thermal conductivity. The composites(epoxy-IOT) used were fabricated by Adedayo and Onitiri (2012). A standard ASTM laboratory sieve was used for the gradation of the ore tailings into a different particle size of $150 \mu \mathrm{m}, 212 \mu \mathrm{m}$ and $300 \mu \mathrm{m}$. The chemical composition of the iron ore tailings is presented in an earlier work by (Adedayo and Onitiri, 2012). The percentage filler loadings $5 \%, 10 \%, 15 \%, 20 \%, 25 \%$, and $30 \%$ was adopted in this work.

\subsection{DeVelopment OF IRON ORE TAILINGS FiLled EPOXY COMPOSITES}

The procedure for the development of iron ore tailings reinforced epoxy composites had been discussed elsewhere (Adedayo and Onitiri, 2012a) and (Adedayo and Onitiri, 2012b). The mixing ratios are presented in Table 1.

Table 1. Mixing Ratios of the Composites

\begin{tabular}{|c|c|c|c|}
\hline $\begin{array}{c}\text { Particle } \\
\text { Size }\end{array}$ & $\begin{array}{c}\text { Epoxy E } \\
(\%)\end{array}$ & $\begin{array}{c}\text { IOT Particle } \\
(\%)\end{array}$ & Code \\
\hline \multirow{7}{*}{$\begin{array}{l}150 \mu \mathrm{m} \\
\text { (B) }\end{array}$} & 100 & 0 & $\mathrm{~A}$ \\
\hline & 95 & 5 & B5 \\
\hline & 90 & 10 & B10 \\
\hline & 85 & 15 & B15 \\
\hline & 80 & 20 & B20 \\
\hline & 75 & 25 & B25 \\
\hline & 70 & 30 & B30 \\
\hline \multirow{7}{*}{$\begin{array}{l}212 \mu \mathrm{m} \\
(\mathrm{C})\end{array}$} & 100 & 0 & A \\
\hline & 95 & 5 & C5 \\
\hline & 90 & 10 & C10 \\
\hline & 85 & 15 & C15 \\
\hline & 80 & 20 & C20 \\
\hline & 75 & 25 & C25 \\
\hline & 70 & 30 & C30 \\
\hline \multirow{7}{*}{$\begin{array}{c}300 \mu \mathrm{m} \\
\text { (D) }\end{array}$} & 100 & 0 & $\mathrm{~A}$ \\
\hline & 95 & 5 & D5 \\
\hline & 90 & 10 & D10 \\
\hline & 85 & 15 & D15 \\
\hline & 80 & 20 & D20 \\
\hline & 75 & 25 & D25 \\
\hline & 70 & 30 & D30 \\
\hline
\end{tabular}

\subsection{Mechanical Properties of the Epoxy-lOT COMPOSITES}

Table 2 presents the volume mix ratios used in this paper, which are $5 \%, 10 \%, 15 \%, 20 \%, 25 \%$ and $30 \%$ with their mechanical properties.

\subsection{Thermal Properties of EpoXy-IOT Composites USING THE KD2 THERMAL ANALYZER}

The thermal properties of the epoxy-IOT composites using KD2 pro thermal properties analyzer are shown in Table 3. The selected composite used in this analysis among all the composites tested is EB10 (epoxy filled iron ore tailings composite with mixing volume of $10 \%$ of particle size of $150 \mu \mathrm{m}$ ), it has a specific heat capacity of $2352 \mathrm{~J} / \mathrm{kg}-\mathrm{K}$, the thermal conductivity of $0.209 \mathrm{~W} / \mathrm{m}-\mathrm{K}$ and density of $998.4 \mathrm{~kg} / \mathrm{m} 3$. The selected composite (EB10) was used as insulation for heat resistant material. Gypsum board has a specific heat capacity of $1090 \mathrm{~J} / \mathrm{Kg}-\mathrm{K}$, thermal conductivity of $0.258 \mathrm{~W} / \mathrm{m}-\mathrm{K}$ and density of $711 \mathrm{~kg} / \mathrm{m} 3$, at room temperature.

Table 2. Ultimate Tensile and Yield Stress (MPa) of Composites with Particle size of $150 \mu \mathrm{m}, 212 \mu \mathrm{m}$, and $300 \mu \mathrm{m}$ of IOT in Epoxy (Adedayo and Onitiri, 2012).

\begin{tabular}{|c|c|c|c|c|c|c|c|c|c|}
\hline \multirow{2}{*}{$\begin{array}{l}\text { Part } \\
\text { icle } \\
\text { size, } \\
\mu \mathrm{m}\end{array}$} & \multicolumn{7}{|c|}{ Volume ratio of iron ore tailings, $\%$} & \multirow[b]{2}{*}{ Mean } & \multirow{2}{*}{$\begin{array}{c}\text { Stan } \\
\text { dard } \\
\text { devi } \\
\text { atio } \\
\text { n }\end{array}$} \\
\hline & 0 & 5 & 10 & 15 & 20 & 25 & 30 & & \\
\hline \multicolumn{10}{|c|}{ Yield Stress } \\
\hline 150 & 5.0 & 2.0 & 2.0 & 2.0 & 0.5 & 3.0 & 3.0 & 2.91 & 1.45 \\
\hline 212 & 5.0 & 0.6 & 5.0 & 2.5 & 2.5 & 0.3 & 1.0 & 2.81 & 2.01 \\
\hline 300 & 5.0 & 0.3 & 0.2 & 0.5 & 0.5 & 0.5 & 1.0 & 1.33 & 1.73 \\
\hline \multicolumn{10}{|c|}{ Ultimate Stress } \\
\hline 150 & 40 & 15 & 3 & 36 & 30.0 & 20 & 25.0 & 33.00 & $\begin{array}{c}10.2 \\
1\end{array}$ \\
\hline 212 & 40 & 35 & 50 & 35 & 32.5 & 30 & 35.0 & 42.92 & 9.33 \\
\hline 300 & 40 & 34 & 32 & 38 & 32.5 & 24 & 32.0 & 38.67 & 7.88 \\
\hline
\end{tabular}

\subsection{Numerical InVEStigation OF the Thermal PERFORMANCE OF EPOXY-IOT COMPOSITE.}

A composite from the experimental results is selected and compared with an existing material (gypsum board), which is known to be a heat resistant material using its thermal properties. The numerical analysis is carried out to determine the thermal performance of the two materials (the epoxy-IOT composite and gypsum plasterboard) as heat resistant material and compare the result using the same dimension, boundary and initial conditions. The parameters and materials needed are:

- The slabs were modelled with their thermal properties

- The thickness of the slabs was varied using $12.7 \mathrm{~mm}, 15.9 \mathrm{~mm}$ and $19.05 \mathrm{~mm}$ while the length $(152 \mathrm{~mm})$ and the width $(152 \mathrm{~mm})$ remain constant.

- Heat flux of $50 \mathrm{~kW} / \mathrm{m}^{2}$ and $75 \mathrm{~kW} / \mathrm{m}^{2}$ were used in the analysis

- A convective heat transfer method was used.

\subsubsection{Numerical Simulation of the Existing Material} (Gypsum Board) and Novel Composite

The slab was modelled using Autodesk Fusion360 software with the dimension of length $152 \mathrm{~mm}$ and width $152 \mathrm{~mm}$ while the thickness was varied using $12.7 \mathrm{~mm}$, $15.9 \mathrm{~mm}$ and $19.05 \mathrm{~mm}$. Thermal analysis was conducted with the same software, heat fluxes of $50 \mathrm{~kW} / \mathrm{m}^{2}$ and 75 $\mathrm{kW} / \mathrm{m}^{2}$ was applied differently on one surface of the slab and kept the other surface at $25^{\circ} \mathrm{C}$ while using convective heat transfer method. Also, a thermal stress analysis was conducted using the same software, heat fluxes of 50 $\mathrm{kW} / \mathrm{m}^{2}$ and $75 \mathrm{~kW} / \mathrm{m}^{2}$ was applied differently on one surface of the slab while constrained all the edges of the slab. A transient thermal analysis is used to run the simulations. 
Table 3. Thermal properties of epoxy-IOT composites (Oyebode et al, 2020)

\begin{tabular}{|c|c|c|c|c|c|c|c|c|}
\hline $\begin{array}{l}\text { Particle } \\
\text { Size }\end{array}$ & $\begin{array}{c}\text { Epoxy E } \\
(\%)\end{array}$ & $\begin{array}{l}\text { IOT } \\
(\%)\end{array}$ & Code & $\begin{array}{c}\text { Thermal } \\
\text { Conductivity } \\
\text { (W/mK) }\end{array}$ & $\begin{array}{c}\text { Thermal } \\
\text { Diffusivity } \\
\left(\mathrm{mm}^{2} / \mathbf{s}\right)\end{array}$ & $\begin{array}{c}\text { Thermal } \\
\text { Resistivity } \\
\left({ }^{\circ} \mathrm{C}-\mathrm{m} / \mathrm{W}\right)\end{array}$ & $\begin{array}{c}\text { Specific Heat } \\
\text { Capacity } \\
\left(\mathrm{MJ} / \mathrm{m}^{3} \mathrm{~K}\right)\end{array}$ & $\begin{array}{c}\text { Temperature } \\
\left({ }^{\circ} \mathrm{C}\right)\end{array}$ \\
\hline $\begin{array}{l}\text { Pure } \\
\text { Epoxy }\end{array}$ & 100 & 0 & A & 0.573 & 1.225 & 0.175 & 0.467 & 31.02 \\
\hline \multirow[t]{6}{*}{$\begin{array}{c}150 \mu m \\
(\mathrm{~EB}) \\
\end{array}$} & 95 & 5 & EB5 & 0.250 & 0.192 & 0.400 & 1.303 & 29.43 \\
\hline & 90 & 10 & EB10 & 0.209 & 0.089 & 0.478 & 2.352 & 28.81 \\
\hline & 85 & 15 & EB15 & 0.451 & 0.203 & 0.222 & 2.227 & 29.81 \\
\hline & 80 & 20 & EB20 & 0.593 & 0.405 & 0.169 & 1.463 & 29.97 \\
\hline & 75 & 25 & EB25 & 0.895 & 0.782 & 0.112 & 1.144 & 30.44 \\
\hline & 70 & 30 & EB30 & 0.345 & 0.261 & 0.290 & 1.320 & 30.59 \\
\hline \multirow[t]{6}{*}{$\begin{array}{c}212 \mu \mathrm{m} \\
(\mathrm{EC}) \\
\end{array}$} & 95 & 5 & EC5 & 0.168 & 0.592 & 0.596 & 0.283 & 31.21 \\
\hline & 90 & 10 & EC10 & 0.221 & 0.276 & 0.452 & 0.801 & 30.55 \\
\hline & 85 & 15 & EC15 & 0.269 & 0.580 & 0.372 & 0.464 & 30.42 \\
\hline & 80 & 20 & EC20 & 0.421 & 0.331 & 0.235 & 1.257 & 30.72 \\
\hline & 75 & 25 & EC25 & 0.277 & 0.446 & 0.361 & 0.621 & 30.72 \\
\hline & 70 & 30 & EC30 & 0.835 & 0.630 & 0.120 & 1.326 & 30.73 \\
\hline \multirow[t]{6}{*}{$\begin{array}{c}300 \mu m \\
(\mathrm{ED}) \\
\end{array}$} & 95 & 5 & ED5 & 0.711 & 0.864 & 0.141 & 0.823 & 30.92 \\
\hline & 90 & 10 & ED10 & 0.492 & 0.600 & 0.203 & 0.820 & 30.42 \\
\hline & 85 & 15 & ED15 & 0.204 & 0.557 & 0.490 & 0.366 & 30.85 \\
\hline & 80 & 20 & ED20 & 0.398 & 0.301 & 0.253 & 1.323 & 30.83 \\
\hline & 75 & 25 & ED25 & 0.373 & 0.625 & 0.268 & 0.597 & 30.34 \\
\hline & 70 & 30 & ED30 & 0.464 & 0.424 & 0.215 & 1.095 & 30.22 \\
\hline
\end{tabular}

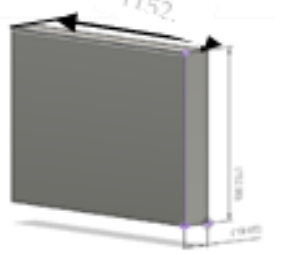

Fig. 1: Numerical modeling of slab

The boundary conditions used are: (a) Initial temperature boundary at the unexposed face of the slab and (b) Constant heat flux of $50 \mathrm{~kW} / \mathrm{m}^{2}$ and $75 \mathrm{~kW} / \mathrm{m}^{2}$ were applied at the exposed face of the slab

\subsubsection{Mathematical Modelling}

The non-linear partial differential equation is the governing equation used for the heat transfer using the CFD tool. The equation used is conservation of energy equations for one-dimensional heat transfer. The equations denote the mathematical formulars of natural convection problems.

Conservation of energy: The equation of heat is a conservation of energy equation that states that change in energy is equated to the heat source minus the divergence of the diffusive heat flux for one-dimensional heat and mass transfer in the control volume;

$$
\rho C_{p}(T) \frac{\partial T}{\partial t}=\frac{\partial}{\partial x}\left(k(T) \frac{\partial T}{\partial x}\right)+G
$$

where, $x$ is depth of wall from exposed surface $(m) ; t$ is time (s); $G$ is the thermal energy generation rate per unit volume $\left(\mathrm{W} / \mathrm{m}^{3}\right)$; $\mathrm{T}$ is the temperature $\left({ }^{\circ} \mathrm{C}\right), \mathrm{k} \quad$ is the thermal conductivity $(\mathrm{W} / \mathrm{m} \cdot \mathrm{K}) ; \mathrm{Q}$ is the density $\left(\mathrm{kg} / \mathrm{m}^{3}\right)$ and $\mathrm{Cp}$ is the specific heat $(\mathrm{J} / \mathrm{kg} \cdot \mathrm{K})$.

The thermal energy generation rate per unit volume $\left(\mathrm{W} / \mathrm{m}^{3}\right)$ linked with change in phases and thermochemical reactions is presumed to determine the use of the appropriate method for the heat capacity. Therefore, the governing equation becomes;

$$
\rho C_{p}(T) \frac{\partial T}{\partial t}=\frac{\partial}{\partial x}\left(k(T) \frac{\partial T}{\partial x}\right)
$$

\section{Result ANd Discussion}

Tables 4 and 5 show the comparison of the numerical simulation results between the epoxy-IOT composite and the existing material (gypsum board).

\subsection{Results Comparison OF the Temperature DISTRIBUTION OF GYPSUM BOARD AND EPOXY-IOT}

Figures 3 to 8 show the comparison results of the temperature distribution between the epoxy-IOT composite and the existing material (gypsum board). From figure 2, it shows that the minimum temperature of the epoxy-IOT composite is $7.51 \%$ lesser than that of the gypsum board, which implies that it is a better insulator than the gypsum board of the same geometry and the same thermal condition. 
Table 4. Simulation results for thermal stress of gypsum board and epoxy-IOT composite

\begin{tabular}{|c|c|c|c|c|c|c|c|c|c|}
\hline \multirow{4}{*}{$\mathrm{S} / \mathrm{N}$} & \multirow{4}{*}{ Thickness (mm) } & \multicolumn{8}{|c|}{ THERMAL STRESS (MPa) } \\
\hline & & \multicolumn{4}{|c|}{ Heat Flux-50kW/m² } & \multicolumn{4}{|c|}{ Heat Flux-50kW/m² } \\
\hline & & \multicolumn{2}{|c|}{ Gypsum Board } & \multicolumn{2}{|c|}{ Epoxy-IOT } & \multicolumn{2}{|c|}{ Gypsum Board } & \multicolumn{2}{|c|}{ Epoxy-IOT } \\
\hline & & Max & Min & Max & Min & Max & Min & Max & Min \\
\hline 1 & 12.1 & 42624 & 309 & 3.191 & 0.018 & 93928 & 463 & 4.786 & 0.026 \\
\hline 2 & 15.9 & 44461 & 253 & 3.356 & 0.015 & 66683 & 380 & 4.033 & 0.022 \\
\hline 3 & 19.05 & 48599 & 216 & 3.699 & 0.016 & 72890 & 324 & 5.548 & 0.024 \\
\hline
\end{tabular}

Table 5. Simulation results for temperature distribution of gypsum board and epoxy-IOT composite

\begin{tabular}{|c|c|c|c|c|c|c|c|c|c|}
\hline \multirow{4}{*}{$\mathrm{S} / \mathrm{N}$} & \multirow{4}{*}{$\begin{array}{l}\text { Thickness } \\
\text { (mm) }\end{array}$} & \multicolumn{8}{|c|}{ TEMPERATURE DISTRIBUTION (K) } \\
\hline & & \multicolumn{4}{|c|}{ Heat Flux-50kW/m² } & \multicolumn{4}{|c|}{ Heat Flux-50kW/m² } \\
\hline & & \multicolumn{2}{|c|}{ Gypsum Board } & \multicolumn{2}{|c|}{ Epoxy-IOT } & \multicolumn{2}{|c|}{ Gypsum Board } & \multicolumn{2}{|c|}{ Epoxy-IOT } \\
\hline & & Max & Min & Max & Min & Max & Min & Max & Min \\
\hline 1 & 12.1 & 11918 & 4649 & 12630 & 4300 & 17729 & 6824 & 18795 & 6301 \\
\hline 2 & 15.9 & 12101 & 4265 & 12978 & 3919 & 18002 & 6248 & 19318 & 5729 \\
\hline 3 & 19.05 & 12237 & 3943 & 13262 & 3601 & 18206 & 5766 & 19744 & 5253 \\
\hline
\end{tabular}

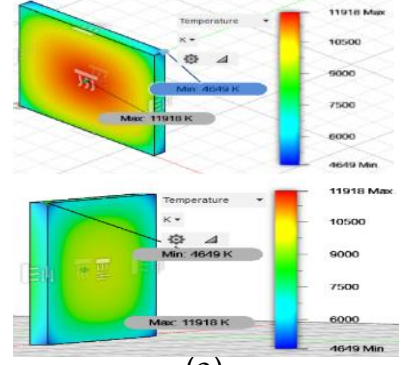

(a)

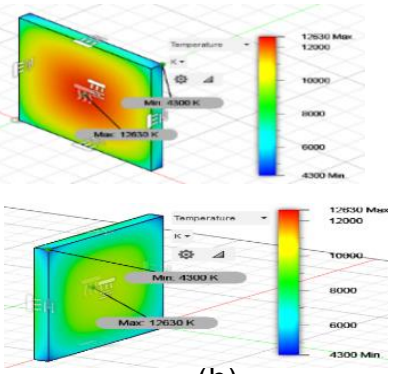

(b)

Fig. 2: Comparison of temperature distribution of $12.7 \mathrm{~mm}$ for heat flux of $50 \mathrm{~kW} / \mathrm{m}^{2}$ (a) gypsum board (b) epoxy-IOT

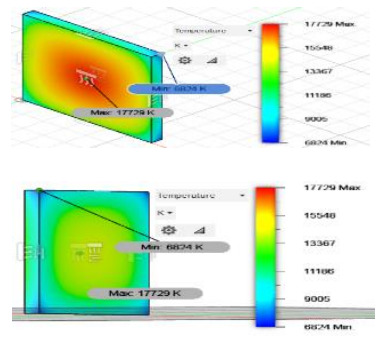

(a)

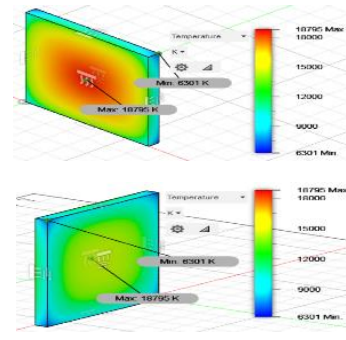

(b)
Fig. 3: Comparison of temperature distribution of $12.7 \mathrm{~mm}$ for heat flux of $75 \mathrm{~kW} / \mathrm{m}^{2}$ (a) gypsum board (b) epoxy-IOT

From tigure 3 , it shows that the minimum temperature of the epoxy-IOT composite is $7.66 \%$ lesser than that of the gypsum board, which implies that it is a better insulator than the gypsum board of the same geometry and the same thermal condition.

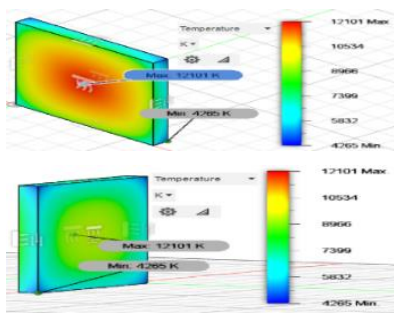

(a)

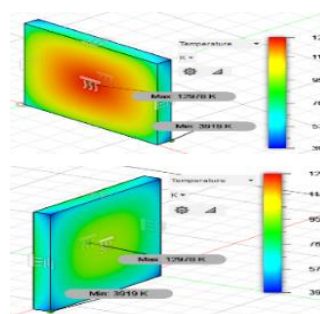

(b)
Fig. 4: Comparison of temperature distribution of $15.9 \mathrm{~mm}$ for heat flux of $50 \mathrm{~kW} / \mathrm{m}^{2}$ (a) gypsum board (b) epoxy-IOT
From figure 4, it shows that the minimum temperature of the epoxy-IOT composite is $8.11 \%$ lesser than that of the gypsum board, which implies that it is a better insulator than the gypsum board of the same geometry and the same thermal condition.

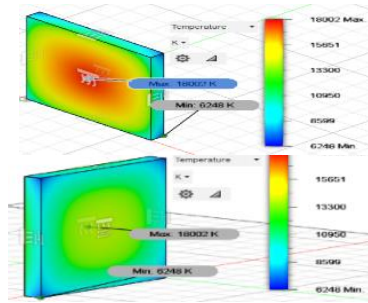

(a)

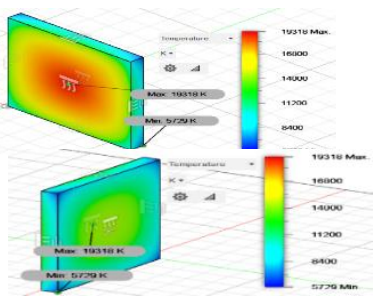

(b)
Fig. 5: Comparison of temperature distribution of $15.9 \mathrm{~mm}$ for heat flux of $75 \mathrm{~kW} / \mathrm{m} 2$ (a) gypsum board (b) epoxy-IOT

From figure 5, it shows that the minimum temperature of the epoxy-IOT composite is $8.31 \%$ lesser than that of the gypsum board, which implies that it is a better insulator than the gypsum board of the same geometry and the same thermal condition.

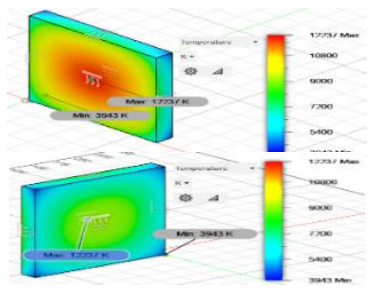

(a)

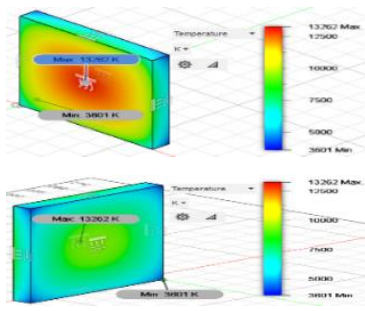

(b)
Fig.6: Comparison of temperature distribution of $19.05 \mathrm{~mm}$ for heat flux of $50 \mathrm{~kW} / \mathrm{m} 2$ (a) gypsum board (b) epoxy-IOT

From figure 6, it shows that the minimum temperature of the epoxy-IOT composite is $8.67 \%$ lesser than that of the gypsum board, which implies that it is a better insulator than the gypsum board of the same geometry and the same thermal condition 

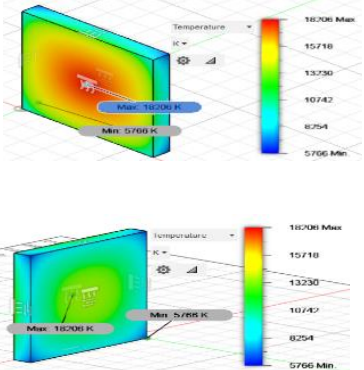

(a)
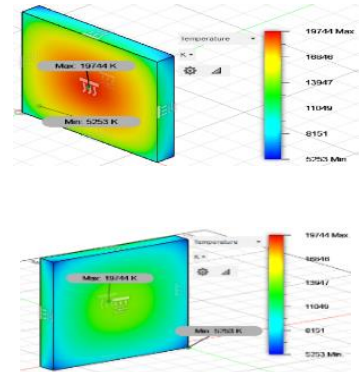

(b)
Fig. 7: Comparison of temperature distribution of $19.05 \mathrm{~mm}$ for heat flux of $75 \mathrm{~kW} / \mathrm{m} 2$ (a) gypsum board (b) epoxy-IOT

From figure 7, it shows that the minimum temperature of the epoxy-IOT composite is $8.90 \%$ lesser than that of the gypsum board, which implies that it is a better insulator than the gypsum board of the same geometry.

\subsection{The Results Comparison OF the THERMAL STRESS OF GYPSUM BOARD AND EPOXY-IOT}

From figures $9-13$, the simulation results show that Epoxy-IOT composite has lower thermal stress which implies that it will sustain thermal stress better than gypsum board of the same geometry and the same thermal condition

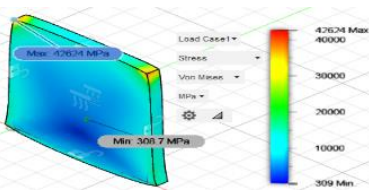

(a)

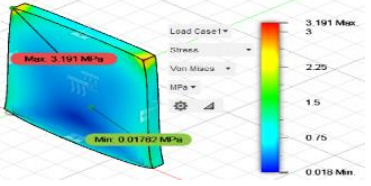

(b)
Fig. 8: Comparison of thermal stress of $12.7 \mathrm{~mm}$ for heat flux of $50 \mathrm{~kW} / \mathrm{m}^{2}$ (a) avpsum board (b) epoxv-IOT

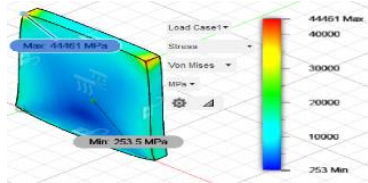

(a)

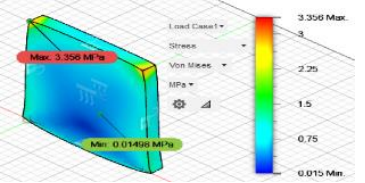

(b)
Fig. 9: Comparison of thermal stress of $12.7 \mathrm{~mm}$ for heat flux of $75 \mathrm{~kW} / \mathrm{m}^{2}$ (a) gypsum board (b) epoxy-IOT

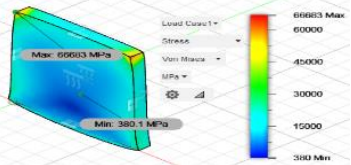

(a)

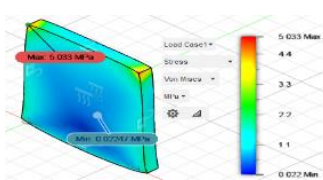

(b)
Fig. 10: Comparison of thermal stress of $15.9 \mathrm{~mm}$ for heat flux of $50 \mathrm{~kW} / \mathrm{m}^{2}$ (a) gypsum board (b) epoxy-IOT

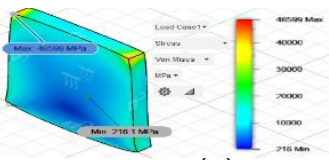

(a)

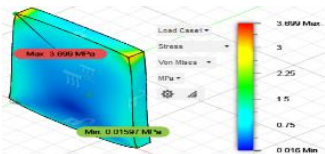

(b)
Fig. 11: Comparison of thermal stress of $15.9 \mathrm{~mm}$ for heat flux of $75 \mathrm{~kW} / \mathrm{m}^{2}$ (a) gypsum board (b) epoxy-IOT

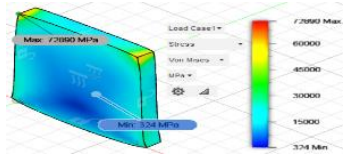

(a)

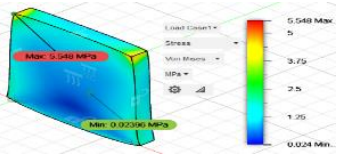

(b)
Fig. 12: Comparison of thermal stress of $19.05 \mathrm{~mm}$ for heat flux of $50 \mathrm{~kW} / \mathrm{m}^{2}$ (a) gypsum board (b) epoxy-IOT

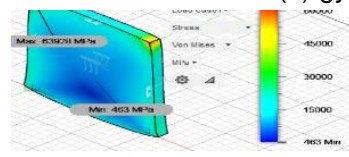

(a)

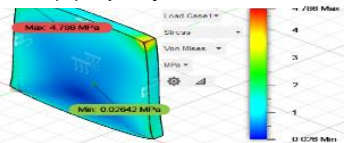

(b)
Fig. 13: Comparison of thermal stress of $19.05 \mathrm{~mm}$ for heat flux of $75 \mathrm{~kW} / \mathrm{m}^{2}$ (a) gypsum board (b) epoxy-IOT

\subsection{GRAPHS OF the Simulation RESULTS OF GyPSUM BOARD AND EPOXY-IOT COMPOSITE AGAINST THICKNESS}

Figures show the plots of the thermal stress and the minimum temperature of gypsum board and epoxy-IOT composite against thickness.

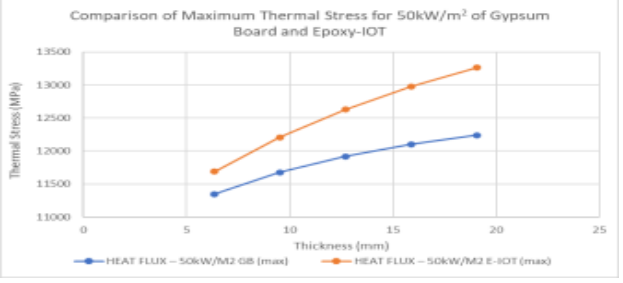

(a)

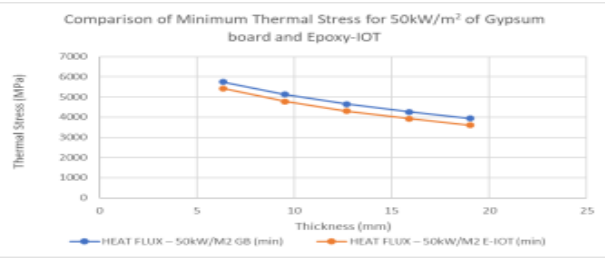

(b)

Fig. 14: Graphical comparison of (a) maximum and (b) minimum thermal stress for $50 \mathrm{~kW} / \mathrm{m}^{2}$ of gypsum board and epoxy-IOT

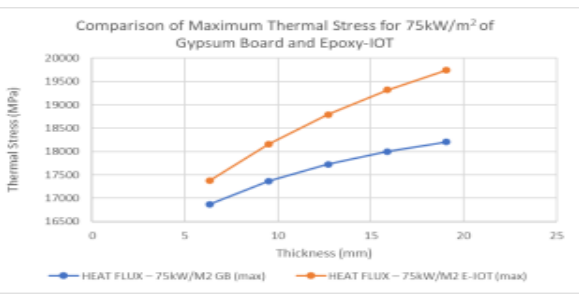

(a)

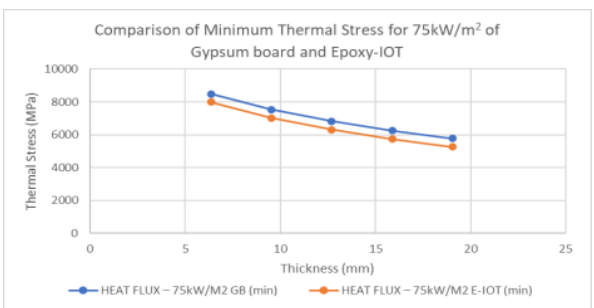

(b)

Fig. 15: Graphical comparison of (a)maximum and (b) minimum thermal stress for $75 \mathrm{~kW} / \mathrm{m}^{2}$ of gypsum board and epoxy-IOT 


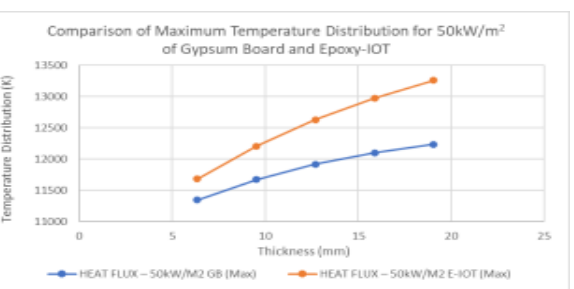

(a)

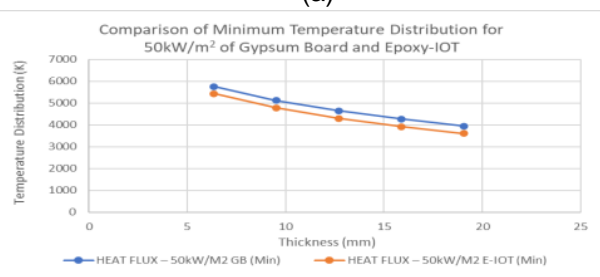

(b)

Fig. 16: Graphical comparison of (a) maximum and (b) minimum temperature distribution for $50 \mathrm{~kW} / \mathrm{m}^{2}$ of gypsum board and epoxy-IOT

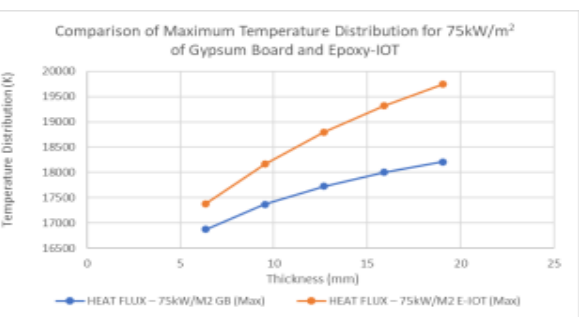

(a)

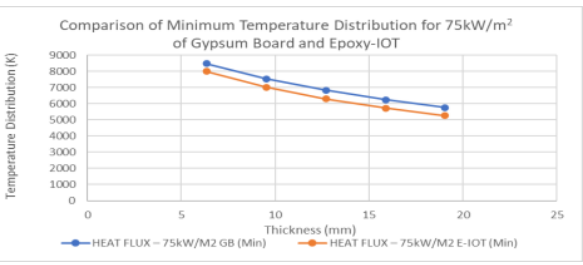

(b)

Fig. 17: Graphical comparison of (a) maximum and (b) minimum temperature distribution for $75 \mathrm{~kW} / \mathrm{m}^{2}$ of gypsum board and epoxy-IOT

It was shown that the epoxy-IOT composites with different sizes were better insulators than the gypsum board, having lower minimum temperatures at the cold faces of the slabs and sustained thermal stress better when subjected to the same conditions due to the strong bond and less pores in the composite that make it denser.

\section{CONCLUSIONS}

The heat transfer analysis of the existing material (gypsum board) and the epoxy-IOT composite of EB10 as insulator materials was conducted. The materials were modelled as slabs with the same dimension (geometry) and subjecting them under the same conditions. Gypsum board is a good insulator of heat with desirable properties, usually used for heat resistant applications. However, from the numerical investigation conducted in this paper, it is observed that the epoxy-IOT composite can suitably replace the gypsum board.

Thus, epoxy-IOT composite can be recommended for heat resistant material over gypsum board with its advantages qualities such as naturally occurring, availability, not being brittle (can't easily crack), suitable for inside and outer construction, not being vulnerable to moisture, cannot be infested by termites nor mold, and cost-effective.

\section{REFERENCES}

Adedayo, S. M. \& Onitiri, M. A. (2012a). Tensile of iron ore tailings filled epoxy composites. The West Indian J. of Engineering. 35(1), 51-59.

Adedayo, S. M. \& Onitiri, M. A. (2012b). Mechanical properties of iron ore tailings filled-polypropylene composites. Journals of Minerals \& Materials Characterization \& Engineering. 11( 7), 671-678.

Aire, C. T. (2014). Experimental and Numerical Modeling of Heat Transfer in Wall Assemblies. University of Saskatchewan, Saskatoon.

Brito, Z. \& Sanchez, G. (2000). Influence of metallic fillers on the thermal and mechanical behavior in composites of epoxy matrix. Composite Structures, 48, 79 - 81 .

Brown, C., \& Milke, M. (2016). Recycling disaster waste: feasibility, method and effectiveness. Resource. Conservation. Recycling. 106:21-32 DOI: 10.1016/j.resconrec.2015.10.021.

Gypsum Association (2010). Gypsum Board Typical Mechanical and Physical Properties (GA-235-10. 6525 Belcerest Road, Suite 480, Hyattsville MD 20782; USA.

Habes, A.G. \& Fares, M.H. (2011). Gypsum: Properties, Production and Applications. ISBN: 978-1-61728-308-6.

Hwang, C.L. \& Huynh, T.P. (2015). Effect of alkali-activator and rice husk ash content on strength development of fly ash and residual rice husk ash-based geopolymers. Constr. Build. Mater. 101, 1-9.

Ima, R. (2011). Thermal and Mechanical Properties of Gypsum Boards and Their Influences on Fire Resistance of Gypsum Board Based Systems. University of Manchester, UK.

Kuranchie, F.A., Sanjay, K.S., Daryoush, H. \& Alireza, M. (2015). Utilization of iron ore tailings as aggregates in concrete. Cogent Engineering, Volume 2.

Olukayode, D. \& Akinyemi, Y. S. (2012). Determination of Thermal Properties of Rock Samples Using modified thermal block. Earth Science India, eISSN: 0974-8350, 4-5.

Onitiri, M. A. \& Akinlabi, E. T. (2017). Effects of particle size and particle loading on the tensile properties of iron-ore-tailingfilled epoxy and polypropylene composites. Mechanics of Composite Materials, 52(6).

Ouyang, A. F. (2005) Implementation of Creep Failure in Polymer Matrix Composites with Transverse Isotropy. M.Sc. Thesis. Graduate Faculty of the University of Akron. U.S.A.

Oyebode, J., Mbagwu, V., Onitiri, M., \& Adewumi O. (2020). Effect of Iron Ore Tailings Particle Sizes on the Thermal Properties of Epoxy and Polypropylene Matrix Composites. FUOYE Journal of Engineering and Technology (FUOYEJET), 5(2)

Ravichandran, G. \& Liu, C. T. (1995). Modelling Constitutive Behaviour of Particulate Composites Undergoing Dam- age. International Journal of Solids and Structures, Vol. 32, No. 6-7, pp. 979-990.

Shwetha, R. A. (2017). Study on Utilization of Iron Ore Tailings as Fine Aggregates and GGBS as Partial Substitute in Concrete. International Journal of Engineering Research \& Technology (IJERT), ISSN:2278-0181, 6(6).

Van Dommelen, J. A. W., Brekelmans, W. A. M. \& Baaijens, F. P. T. (2003). A Numerical Investigation of the Potential of Rubber and Mineral Particles for Toughening of Semi- Crystalline Polymers. Computational Materials Science, 27(4), 480-492.

Zelibe, C.G. (2018). Determination of the Thermal Properties of Fibre Glass Talc Epoxy-Filled Composites for Heating Applications. Masters Thesis, University of Lagos, Nigeria. 